\title{
Legal Regulation of Standardization and Certification of Space Objects
}

\author{
Olha Yeshchuk
}

Doctor of Law, Associate Professor of the Department of Administrative and Economic Law and lawenforcement activity of Kherson State University (Kherson, Ukraine)

E-mail: eschyk-o@ukr.net

https://orcid.org/0000-0002-7458-1595

\section{Mariia Novikova}

Ph.D. in Law, Associate Professor, Kherson State University

(Kherson, Ukraine)

E-mail: mariyanna@i.ua

https://orcid.org/0000-0002-0334-3979

The article provides a comparative analysis of international law and national legislation of Ukraine on the legal regulation of space activities. Such institutions of state regulation of objects of space activities as registration and certification are investigated. The problems of legal responsibility of subjects of ownership of space objects in case of expansion of space activities in Ukraine to the private sector are revealed. The article focuses on the fact that in Ukraine there are a number of organizational and legal problems in the field of space activities. Organizational problems include the low level of awareness of the population of Ukraine regarding the goals and objectives of space activities; the lack of qualified legal support for space activities in Ukraine; corruption and insufficient attention by the government to the development of the space industry. The problems of legal regulation of space activities, including the protection of property rights to space objects, include: the lack of proper systematization of national legislation; the delay in the adoption of policy documents in the field of space activities; the declarativity of most of the adopted norms in this area. The adoption of the Law of Ukraine, allowing private space activities, is proposed. The study will contribute to the development of a systematic approach in legislation to the protection of property rights to space objects in accordance with the international legal regulation of the activities of States in the field of protection of property rights to space objects and the like.

The adoption of the Law of Ukraine "On Private Space Activities" is proposed. The study will contribute to the development of a systematic approach in national legislation to the protection of property rights to space objects in accordance with the international legal regulation of the activities of states in the field of protection of property rights to space objects and the like.

Keywords: space objects, space technology, registration, certification, standardization, law, space activities, legal responsibility, private companies

Received: September 22, 2019; accepted: October 24, 2019

(C) Yeshchuk, Olha, 2019

(C) Novikova, Mariia, 2019 
Advanced Space Law, Volume 4, 2019: 107-115.

https://doi.org/10.29202/asl/2019/4/10

\section{Introduction}

Activities in the exploration and use of outer space began to develop a little more than 50 years ago. And even today it is impossible to imagine the life of a modern man without space technologies: telecommunications, satellite navigation, remote sensing of Earth from space, predictions of natural disasters and weather fluctuations, the search for minerals and the like. In just half a century of manned space exploration, representatives of more than 35 countries have visited space. International crews of astronauts have been working in orbit as part of the International space station for the past fifteen years. Space tourism is also beginning to develop [Stelmah, 2016: 3].

Along with the undoubted benefits of space technologies, the exploration and use of outer space is associated with a number of risks, threats and challenges that pose a danger to both Earth's population and outer space, as well as to humans and other biological beings in space. That is why the security of space activities in recent years has become one of the most serious problems of space activities [Stelmah, 2016: 3]. However, there is still a number of problems that we will consider in this article. The relevance of the article is due to the lack of comprehensive studies devoted to legal regulation of standardization and certification of space objects. In particular, issues relating to: the defense and protection of the ownership of space objects; the registration of both civil and military satellites; and the protection of the environment remain under-addressed. Despite the substantial legal framework in this area, which includes a set of conventions, agreements and covenants developed at both the universal and regional levels, all these issues require a comprehensive solution.

\section{Objects of space activity-problems of terminology}

According To the law of Ukraine "On space activities", the term "objects of space activities" is synonymous with the term "space technology" (para. 3. 1). Space activity involves the creation and application of space technology, (space objects), which are material objects of artificial origin, which are designed, manufactured and operated. That is, creation is design and manufacture, and application is operation. The use of these concepts in determining the content of various terms is not entirely appropriate [Stelmakh, 2016: 146].

Unlike celestial bodies of natural origin (such as Moon, planets, etc.), space objects in international space law are understood to be man-made, artificial earth satellites, automatic and manned ships and stations, launch vehicles, etc. International space law regulates activities related to space objects from the moment of their launch or construction in outer space (including on celestial bodies). Until then, their creation and launch activities are within the scope of domestic law, unless otherwise specifically agreed between States (for example, in the case of the joint creation or launch of a space object by several States). After returning to Earth, a space object, as a rule, is again subject to national law, but in the case of its landing on foreign territory, the relations that arise between states are regulated by the rules of international space law [Stelmakh, 2016: 147]. 
The content of the term "objects of space activities (space technology)" covers the peculiar means (objects) by which space activities are carried out (provided) [Stelmakh, 2016: 147].

In the Law, the term "space technology", as noted above, is synonymous with the term "objects of space activities", while distinguishing them into those that are designed, manufactured and operated: in outer space (space segment, space infrastructure); on Earth's surface (ground segment, ground infrastructure) (para. 3 article. 1 of the Law of Ukraine).

In the Law of Ukraine "On space activities" the term "ground infrastructure" is also used, and in the laws of some other countries - the term "space infrastructure" is used [Stelmakh, 2016: 147].

The legislation of Ukraine divides space technology into types for the purpose: for civil, for the needs of dual-purpose defense (Art. 7); for military purposes (Art. 26, 28) [On space, 1996]. Unfortunately, the definition of these terms is not given, so there is confusion in the application of the terms "space technology for defense purposes" and "military purposes". A logical question arises: are they identical or not. It is impossible to draw a final conclusion from the content of the Law of Ukraine "On space activities", since the term "space technology for defense purposes" is used only once (art. 7), which allows us to make an assumption about the randomness of such consumption - instead it was necessary to use the term "military space technology" [Stelmakh, 2016: 147].

Thus, space activities are regulated at the international and national levels. The international level is characterized by the norms contained in multilateral and bilateral treaties concluded by States to regulate public relations in the space sphere. At the national level, activities in the space field are regulated by domestic legislation.

\section{State registration and certification of space objects in Ukraine}

The interest of the world community in the exploration and use of outer space has deep roots dating back to first civilizations. Therefore, it is not surprising that with the development of science and technology and, accordingly, the possibilities of conquering outer space, questions arise about the procedure for carrying out its research, protection, rational use and ensuring the safety of Earth and humanity from the abuse of outer space. The implementation of relations on the exploration and use of outer space has become the basis for the formation of a number of international acts aimed at their settlement. These include the Treaty on principles of the states' activities in the exploration and use of outer space, including Moon and celestial bodies, the Agreement on the rescue of astronauts, the return of astronauts and the return of objects launched into outer space, the Convention on international liability for damage caused by space objects and the like. The norms of these international documents are reflected in the national space law of the signatory countries and form the basis and conditions for the use of outer space at the international and national levels.

Together with the freedom of exploration and use of outer space, the prohibition of placing weapons of mass destruction, international documents set forth special rules under which the state bears direct international liability to cover losses to the affected country and on the basis of the licensing regime should ensure the supervision of compliance of private enterprises with the norms prescribed by international law. National space legislation is intended not only to provide legal regulation of space exploration for the needs of science, but also to contribute to the national defense of these countries. Now space technologies are developing extremely quickly and if earlier at least five years were necessary to launch a satellite, now even four months are enough to prepare a mini-satellite. 
Such national action is presumed to be taken in accordance with the applicable national laws, policies and administrative procedures. They also establish requirements and procedures for private companies to supply the concerned governmental office (keeper of the national registry) with the required information about their launched space objects. Such requirements and procedures are generally imposed through applicable licensing processes. The nature and scope of the information to be entered as well as the timing of recording in the national registry are left to the discretion of each State, though it would be logical that they coincide, as a bare minimum, with the requirements for international registration under Article IV of the Registration Convention [Jakhu et al., 2018].

Therefore, it is very important that national legislation on space activities should comply with generally accepted international norms, and international norms take into account the peculiarities of each state in the use of the law on space exploration.

Any object of space activity in Ukraine is subject to certification for compliance with the requirements of operational suitability established by the regulatory documents in force in Ukraine, with the issuance of a certificate of conformity. The procedure of certification of space technology in Ukraine is determined by the system of certification of space technology of Ukraine, which operates within the framework of the State certification system (UkrSC ST).

State certification is an element of the administrative and legal mechanism of space activity management, which is often used in other fields. For example, certification of energy efficiency of buildings. According to the Law of Ukraine "On Energy Efficiency of Buildings" [On Energy, 2017] mandatory energy efficiency certification is being introduced since 2019 [Soroka, Larysa and all].

The procedure for testing and certification of an imported object of space activity or an object of space activity exported from Ukraine, as well as registration of relevant certification documents is established by the rules of certification of space technology in Ukraine, which are approved by the Cabinet of Ministers of Ukraine.

In addition to the mandatory certification, objects of space activities must be registered with the government. Thus, article 13 of the law of Ukraine "On space activities" contains provisions on registration of spacecraft and unique objects of space activities. Spacecrafts are subject to mandatory state registration in the State register of spacecrafts of Ukraine according to the rules of registration of spacecrafts in Ukraine, which are approved by the Cabinet of Ministers of Ukraine. If a spacecraft is created jointly with legal entities of other states or international organizations, the issue of its registration is resolved in accordance with the concluded international agreements (contracts). A registration certificate is issued for a spacecraft entered in the State register of spacecraft of Ukraine.

After entering the spacecraft into the State register of spacecrafts of Ukraine, all entries concerning this object made earlier in the registers of spacecraft of other States are not recognized by Ukraine.

The inclusion of a spacecraft in the register of spacecraft of another state, if this object is not excluded from the State register of spacecrafts of Ukraine, is not recognized by Ukraine.

In order to ensure the functioning, preservation and further development of unique objects of space activity, the State register of unique objects of space activity is introduced, as well as state supervision over their condition, use and appropriate measures are taken to support the targeted financing of these objects in accordance with the procedure established by the Cabinet of Ministers of Ukraine. 
Article 14 Of the Law of Ukraine "On space activities" contains provisions on the withdrawal of spacecrafts from the State register, therefore the spacecraft is withdrawn from the State register of spacecrafts of Ukraine by the Central Executive body implementing the state policy in the field of space activities in case of: physical destruction (death); transfer in the prescribed manner to another state, international or foreign enterprise, institution or organization.

In case of withdrawal of the spacecraft from the State register of spacecrafts of Ukraine, the registration certificate becomes invalid.

An object of space activity is allowed for operation if it has a certificate of conformity.

The Central Executive authority that implements state policy in the field of space activities may limit or prohibit the operation of space facilities in the event of: delay or absence of certificate of conformity; operation of object of space activity with violation of the current legislation of Ukraine; operation of object of space activity with violation of the requirements of the operational-technical documentation for the object.

\section{International registration of space objects}

It is impossible to ensure the exploration and use of outer space without a full understanding of the situation in outer space. From this point of view such elements play an important role:

1) registration as a means of identifying and establishing a legal link between the object and one of the launchimg states;

2) monitoring (remote sensing) of outer space, which includes the observation and control of the flight of a space object.

Despite the adoption of the Convention on the registration of objects launched into outer space (1974) [Convention, 1974], there remain a number of problems that need to be addressed. The Central registry of space objects the United Nations office for outer space affairs receives information with a large time gap from the moment of launch, which creates certain gaps in the registry, thereby reducing the transparency and completeness of the information it contains.

To address this issue, it would be desirable to establish a time frame within which states and international intergovernmental organizations should provide relevant data. It may also be necessary to provide two stages of reporting and, accordingly, initiate two categories of data (or two divisions of the registry):

1) scheduled launches;

2) launches, that have taken place.

Information about scheduled launches could be given by the providers of launch services, but the registry of launches that have taken place, together with the registration of objects would continue to be implemented as it is today, through diplomatic channels by the state, which according to the agreement between all states that are classified as the states to launch for a specific case, was defined as one that is prepared to assume and perform the duties of the state registration. Another important aspect, which, in our opinion, requires attention, is the strengthening of the means used to identify objects (now we are talking about designations, labeling, etc)

The main purpose of registration, as we noted earlier, is the ability to quickly identify the object. Currently, states are limited to the application of identification marks (designations and markings) mainly on the object as a whole, without taking into account the possibility of destruction of the space object or its disintegration into parts. In the case of collisions in orbit 
or the return of an object to Earth, there may be a situation where certain parts of the object are separated and they can cause harm. There is a situation when the state has fulfilled the obligations arising from the Convention on registration of objects launched into outer space (1974), purely formally. In view of this, it would be appropriate to oblige states to apply a designation, marking, stamp with a registration number, etc. to all large elements of a space object that may be detached [Stelmakh, 2016: 140].

Thus, the main purpose of registration is the possibility of rapid identification of the object. It should be emphasized that, as of today, States are limited to the application of identification marks (designations and markings) mainly on the object as a whole, without taking into account the possibility of destruction of the space object or its disintegration into parts. The Central registry of space objects of the United Nations office for outer space affairs receives information with a large time gap from the moment of launch, which creates certain gaps in the registry, thereby reducing the transparency and completeness of the information it contains. Of course, this situation should be changed, because the registration of satellites as a means of their protection is very important.

\section{Ways to overcome the problems of legal regulation of space activities}

In addition to organizational problems, Ukraine has problems with legal regulation in the sphere that affect not only the general issues of development of Ukraine as a space power, but also concern the issues of ownership of satellite communication systems. In particular, on September 5, 2018, the Cabinet of Ministers of Ukraine approved the Concept of the national target scientific and technical space program of Ukraine for 2018-2022 [On approval, 2018]. Accordingly, the State space Agency, together with other interested Central Executive authorities, was entrusted with the duty to develop and submit, in accordance with the established procedure, for consideration by the Cabinet of Ministers of Ukraine, a draft national target scientific and technical space program of Ukraine for 2018-2022. However, it is still not approved. Now there is a bill № 9457 of 28.12.2018 “On approval of the national target scientific and technical space program of Ukraine for 2019-2023" [Draft, 2018], but 2019 is already expiring, and this bill has not been approved. It should be noted that from the standpoint of legal theory, program documents serve as the basis for the development of the sphere of public relations and its legal regulation. Procrastination with the approval of this program becomes the basis for the haphazard creation of legal norms in the space industry, the reason for the adoption of regulations "as necessary". Accordingly, it creates a pile of unrelated norms that complicate the implementation of public relations, make Ukraine uninteresting for international partnership and foreign investment.

Thus, the issue of launching its own objects of space activity, including military ones, is very relevant for Ukraine. It faces the need to address many issues, including, first of all, changing priorities for the development of the space industry in Ukraine, overcoming corruption, forming a corps of lawyers capable of defending the interests of the Ukrainian state in international courts, improving the quality of diplomatic activity. After all, all these shortcomings exclude Ukraine far back in comparison with other states in the study and exploration of space. This situation looks hopeless in the light of the announcement in November 2019 by the North Atlantic Alliance of space as a separate sphere of operations, which does not exclude its further consideration as a platform for military action. 


\section{Legal liability of private sector entities as owners of space objects}

The Vienna Declaration on space activities and human society development, adopted by the third United Nations conference on the exploration and peaceful uses of outer space (1999), defines environmental protection and the rational use of earth resources as one of the priorities for the development of space activities [Space, 1999]. It is determined that the international community should take all measures to ensure, at the highest possible level, that the implementation of all space activities, especially those that may have adverse environmental effects at the local level and globally, reduces such effects, as well as to take appropriate measures to achieve such an objective. This issue becomes relevant for Ukraine in connection with the adoption by the Verkhovna Rada of Ukraine in the second reading of the draft Law "On amendments to some legislative acts of Ukraine on state regulation of space activities" [On Amendments, 2019], which will enter into force on 29.01.2020. This bill provides for the de-monopolization of space exploration and the involvement of private companies in space activities. Its purpose is to ensure the development, increase investment attractiveness, as well as create a competitive environment for the development of the space industry in Ukraine, along with the public sector of private property enterprises.

With its provisions, the Law of Ukraine "On amendments to some legislative acts of Ukraine on state regulation of space activities" changes a number of existing legal acts, namely: the Laws of Ukraine "On entrepreneurship", "On space activities", "On licensing of kinds of economic activities". However, it does not contain any rules that would determine the procedure for attracting private companies to legal liability as subjects of space activities.

Accordingly, despite quite positive achievements in the development of the space industry, it is necessary to remember the need to comply with international standards of space activities, one of which is the safety of individuals and legal entities, the environment, as well as the protection of the near and far space environment. These standards impose obligations on Ukraine to control the activities of private companies that will engage in space activities on its territory, which in the absence of appropriate legal mechanisms and standards becomes extremely difficult. And in some cases, working with foreign companies is impossible. That is why the clarification of the procedure of legal responsibility of private entities of space activities is the basis for transparent and legal development of the space industry in Ukraine.

In connection with the stated provisions, we consider it necessary to propose instead of amending certain normative acts of Ukraine to develop a draft Law of Ukraine "On private space activities", which should combine international standards of space activities and the peculiarities of national legislation of Ukraine. In particular, it should fix:

- modern principles of private space activity in Ukraine;

- requirements to subjects of private space activity and to establish subjects of the state and public control over this type of activity;

- the range of areas of space activities to which private companies can be involved;

- the list of space objects on creation and use of which the subjects of private space activity will have the right;

- the procedure for the settlement of intellectual property relations in this area;

- features of legal responsibility of subjects of private space activity. 


\section{Conclusion}

Thus, having analyzed the issues related to the protection of property rights to space objects, we come to the conclusion that this problem is quite relevant and many of its aspects in Ukraine are still in the so-called transformational state.

It is established that in Ukraine there are a number of organizational and legal problems in the field of space activities. Organizational problems include the low level of awareness of the population of Ukraine regarding the goals and objectives of space activities; the lack of qualified legal support for space activities in Ukraine; corruption and insufficient attention by the government to the development of the space industry. The problems of legal regulation of space activities, including the protection of property rights to space objects, include: the lack of proper systematization of national legislation; the delay in the adoption of policy documents in the field of space activities; the declarativity of most of the adopted norms in this area.

We believe that the directions of solving these problems in the organizational sphere are increasing the attention of the government to the problems of the space industry in Ukraine, the active participation of state bodies. Improving the legal regulation of space activities in Ukraine provides for the approval of program documents for the development of space activities, systematization of existing legislation in this area with the elimination of differences between regulatory acts. Also one of the priorities is the adoption of the Law of Ukraine "About private space activities", which should solidify: modern principles of private space activities in Ukraine; requirements to the subjects of private space activities and to identify the subjects of state and public control over this kind of activity; a circle of directions of space activity in which private companies can be involved; a list of space objects for creation and use of which the subjects of private space activities will have the right; the procedure for the settlement of intellectual property relations in this sphere; features of legal responsibility of subjects of private space activity.

\section{References}

Convention on Registration of Objects Launched into Outer Space RES 3235 (XXIX). General Assembly 29th session, 1974. https://www.unoosa.org/pdf/gares/ ARES 29 3235E.pdf

Draft Law on Approval of the National Target Scientific and Technical Space Program of Ukraine for 2019-2023. http://w1.c1.rada.gov.ua/pls/zweb2/webproc4_1?pf3511=65308

Eyes of the Ukrainian Army: Today there are three satellites in different stages of development in Ukraine. Zik.ua, 2018. https://zik.ua/news/2018/10/26/ochi_ukrainskoi_armii_ sogodni_v_ukraini_na_riznyh_stadiyah_rozrobky_1435165

Jakhu, Ram S., Bhupendra Jasani, Jonathan C. McDowell. Critical issues related to registration of space objects and transparency of space activities. Acta Astronautica, № 143, 2018. 406-420. https://www.planet4589.org/space/papers/JJM2018/JJM_ published.pdf

On Amendments to Some Legislative Acts of Ukraine on State Regulation of Space Activities. Law of Ukraine of 02.10.2019 № 143-IX. https://zakon.rada.gov.ua/rada/show/143-20/ sp:max 10

On approval of the Concept of the National Target Scientific and Technical Space Program of Ukraine for 2018-2022: Order of the Cabinet of Ministers of Ukraine; Concept from 09/05/2018 № 629-p. https://zakon.rada.gov.ua/laws/main/629-2018-\%D1\%80 
On Energy Efficiency of Buildings. The Law of Ukraine №. 2118-VIII, 2017, June 22. Retrieved from https:// zakon.rada.gov.ua/laws/show/2118-19

On space activities. Law of Ukraine of November 15, 1996 №. 502/96-BP. https://zakon.rada. gov.ua/laws/show/502/96-\%D0\%B2\%D1\%80

Space at the turn of the millennium: Vienna Declaration on Space Activity and Human Society Development of 30.07.1999. https://zakon.rada.gov.ua/laws/show/995_a27

Soroka, Larysa and all. State policy in the field of energy efficiency. Naukovyi Visnyk Natsionalnoho Hirnychoho Universytetu, 2019, №4: 141 -147. https://doi.org/10.29202/ nvngu/2019-4/17

Stelmakh, Olga. International legal regime for the security of peaceful exploration and exploitation of outer space. Institute of State and Law V. M. Koretsky, 2016. 240 p.

Treaty on Principles Governing the Activities of States in the Exploration and Use of Outer Space, including the Moon and Other Celestial Bodies. (United Nations, Treaty Series, Vol. 1363, № 23002), 1967.

The new online service for viewing the changes of the Earth's surface on a monthly basis from Planet. Research Institute of Geodesy and Cartography, 2017. http://gki.com. ua/ua/novi-onlan-servis-dlja-peregljadu-zmin-zemnoii-poverhni-v-schomisjachnomurejimi-vid-kompaniii-planet 